\title{
Enhanced Microbial Survivability in Subzero Brines
}

\author{
Jacob Heinz, Janosch Schirmack, Alessandro Airo, Samuel P. Kounaves, ${ }^{2,3}$ and Dirk Schulze-Makuch ${ }^{1,4}$
}

\begin{abstract}
It is well known that dissolved salts can significantly lower the freezing point of water and thus extend habitability to subzero conditions. However, most investigations thus far have focused on sodium chloride as a solute. In this study, we report on the survivability of the bacterial strain Planococcus halocryophilus in sodium, magnesium, and calcium chloride or perchlorate solutions at temperatures ranging from $+25^{\circ} \mathrm{C}$ to $-30^{\circ} \mathrm{C}$. In addition, we determined the survival rates of $P$. halocryophilus when subjected to multiple freeze/thaw cycles. We found that cells suspended in chloride-containing samples have markedly increased survival rates compared with those in perchlorate-containing samples. In both cases, the survival rates increase with lower temperatures; however, this effect is more pronounced in chloride-containing samples. Furthermore, we found that higher salt concentrations increase survival rates when cells are subjected to freeze/thaw cycles. Our findings have important implications not only for the habitability of cold environments on Earth but also for extraterrestrial environments such as that of Mars, where cold brines might exist in the subsurface and perhaps even appear temporarily at the surface such as at recurring slope lineae. Key Words: Brines-Halophile-MarsPerchlorate-Subzero-Survival. Astrobiology 18, 1171-1180.
\end{abstract}

\section{Introduction}

$\mathbf{L}$ IFE AS WE know it requires liquid water as the principal solvent for its biochemistry, but most planetary surfaces in our Solar System never reach temperatures above the freezing point of pure water, rendering these localities as likely uninhabitable compared with the benign climate conditions on Earth. However, the presence of salts can lead to a substantial freezing point depression down to the eutectic temperature of a given salt/water mixture $\left(e . g .,-50^{\circ} \mathrm{C}\right.$ for a $31 \mathrm{wt} \% \mathrm{CaCl}_{2}$ solution) and, thus, greatly expand the temperature range for potential habitats (Möhlmann and Thomsen, 2011). Hence, the question arises as to whether microorganisms can thrive or at least survive in such subzero brines.

On Earth, microbial organisms such as yeast can tolerate water activities $\left(\mathrm{a}_{\mathrm{w}}\right)$ down to 0.61 (Rummel et al., 2014). However, the lowest salt-induced water activity that halophilic microorganisms can tolerate is that of a saturated $\mathrm{NaCl}$ solution $\left(\mathrm{a}_{\mathrm{w}}=0.75\right)$, while other salts (e.g., those containing $\mathrm{Ca}^{2+}$ and $\mathrm{Mg}^{2+}$ ions) are more inhibitory to cell metabolism (Rummel et al., 2014). Furthermore, it has been reported that certain cyanobacterial species embedded in hygroscopic sodium chloride $(\mathrm{NaCl})$ deposits found in the hyperarid soils of the Atacama Desert are able to utilize water condensed from the atmosphere via deliquescence (Davila et al., 2008; Davila and Schulze-Makuch, 2016).

In addition, many halophilic microorganisms can also be psychrophilic or psychrotolerant (Gounot, 1986; Hoover and Pikuta, 2010). To date, the lowest reported temperature for microbial growth is $-18^{\circ} \mathrm{C}$ for yeast on frozen surfaces (Collins and Buick, 1989). Metabolic ammonia oxidation has been detected down to $-32^{\circ} \mathrm{C}$ (Miteva et al., 2007), and finally, there are indications for photosynthetic activity of lichens at $-40^{\circ} \mathrm{C}$ (de Vera et al., 2014).

It has been argued that low-temperature and high salt tolerances are closely linked, given that at subzero temperatures, water ice forms, which increases the solute concentration of the remaining liquid water (Bakermans, 2012). Moreover, chaotropic agents such as magnesium chloride $\left(\mathrm{MgCl}_{2}\right)$, that is, substances that destroy the bulk water structure and therefore reduce hydrophobic interactions (Gerba, 1984) at moderate concentrations, can decrease the minimal temperature at which cell division can occur for certain microorganisms and increase their growth rates at

\footnotetext{
${ }^{1}$ Center of Astronomy and Astrophysics, Technical University of Berlin, Berlin, Germany.

${ }^{2}$ Department of Chemistry, Tufts University, Medford, Massachusetts.

${ }^{3}$ Department of Earth Science and Engineering, Imperial College London, London, United Kingdom.

${ }^{4}$ School of the Environment, Washington State University, Pullman, Washington.
}

(c) Jacob Heinz et al., 2018; Published by Mary Ann Liebert, Inc. This Open Access article is distributed under the terms of the Creative Commons License (http://creativecommons.org/licenses/by/4.0), which permits unrestricted use, distribution, and reproduction in any medium, provided the original work is properly credited. 
low temperatures, presumably by increasing the macromolecular flexibility (Chin et al., 2010). Furthermore, some microorganisms shift their salinity optimum for growth to higher salt concentrations if exposed to lower temperatures (Gilichinsky et al., 2003).

Organisms have evolved several adaptations for thriving and/or surviving in cold saline environments. These include production of antifreeze or ice-binding proteins, cryoprotectants, or extracellular polymeric substances (Jia et al., 1996; Gilbert et al., 2005; Kuhlmann et al., 2011), an increase of fatty acids that branch and maintain membrane fluidity (Denich et al., 2003), a higher antioxidant defense against reactive oxygen species (Chattopadhyay et al., 2011), the expression of isozymes adapted to low temperatures and high salinities (Maki et al., 2006), or the exclusion of inhibitory ions by accumulating intercellular compatible solutes (Csonka, 1989).

Most of the studies dealing with brines at subzero temperatures have focused on $\mathrm{NaCl}$ as a solute, the most common salt found in saline environments on Earth. However, certain environments on Earth are dominated by high concentrations of other salts such as calcium chloride $\left(\mathrm{CaCl}_{2}\right)$ in Don Juan Pond, Antarctica (Cameron et al., 1972; Dickson et al., 2013), or sodium and magnesium sulfates in Spotted Lake, Canada (Pontefract et al., 2017). Furthermore, martian soils are known to contain various chloride $\left(\mathrm{Cl}^{-}\right)$and perchlorate $\left(\mathrm{ClO}_{4}{ }^{-}\right)$salts (Hecht et al., 2009; Kounaves et al., 2010), emphasizing the importance of research in the field of non$\mathrm{NaCl}$ briny habitats at subzero temperatures.

In this study, we used the halo- and cryotolerant bacterial strain Planococcus halocryophilus Or1 (DSM 24743 ${ }^{\mathrm{T}}$ ) isolated from the active layer of permafrost soil in the Canadian High Arctic (Mykytczuk et al., 2012). This organism grows at temperatures between $-15^{\circ} \mathrm{C}$ and $+37^{\circ} \mathrm{C}$ and under $\mathrm{NaCl}$ concentrations of up to $19 \mathrm{wt} \%$ at which metabolic activity has been detected at temperatures down to $-25^{\circ} \mathrm{C}$ (Mykytczuk et al., 2013).

This bacterial strain shows many cold and osmotic stress responses such as the expression of cold-adapted proteins, the expression of various osmolyte transporters, a high lipid turnover rate, a high resource efficiency at cold temperatures with an accumulation of carbohydrates as a energy resource (Mykytczuk et al., 2013), and complex changes in protein abundances (Raymond-Bouchard et al., 2017). Furthermore, under cold growth conditions, $P$. halocryophilus develops a nodular sheet-like crust around the cells (Ronholm et al., 2015; Mykytczuk et al., 2016).

The above-described ability of $P$. halocryophilus to cope with low temperatures and high salt concentrations makes it an ideal organism for studying whether, and how well, terrestrial life might be able to survive or even thrive in martian environments. In particular, we have investigated how well $P$. halocryophilus can survive repeated freezing/thawing cycles and in subzero chloride and perchlorate brines, since such conditions may be temporarily present on Mars (Martínez and Renno, 2013).

\section{Materials and Methods}

\subsection{Strain and culture conditions}

We used the bacterial strain Planococcus halocryophilus Or1 (DSM 24743 ${ }^{\mathrm{T}}$ ), which was obtained from the DSMZ (Leibniz Institute DSMZ-German Collection of Microorganisms and Cell Cultures). P. halocryophilus was grown in DMSZ growth medium \#92 containing additional $10 \mathrm{wt} \%$ $\mathrm{NaCl}$. Its growth curve at $25^{\circ} \mathrm{C}$ was determined via colony forming units (CFUs), and cell suspensions used for inoculating the experiments were either retrieved after 4 days (sample type ST 1) or 7 days (sample type ST 2) of growth (Fig. 1).

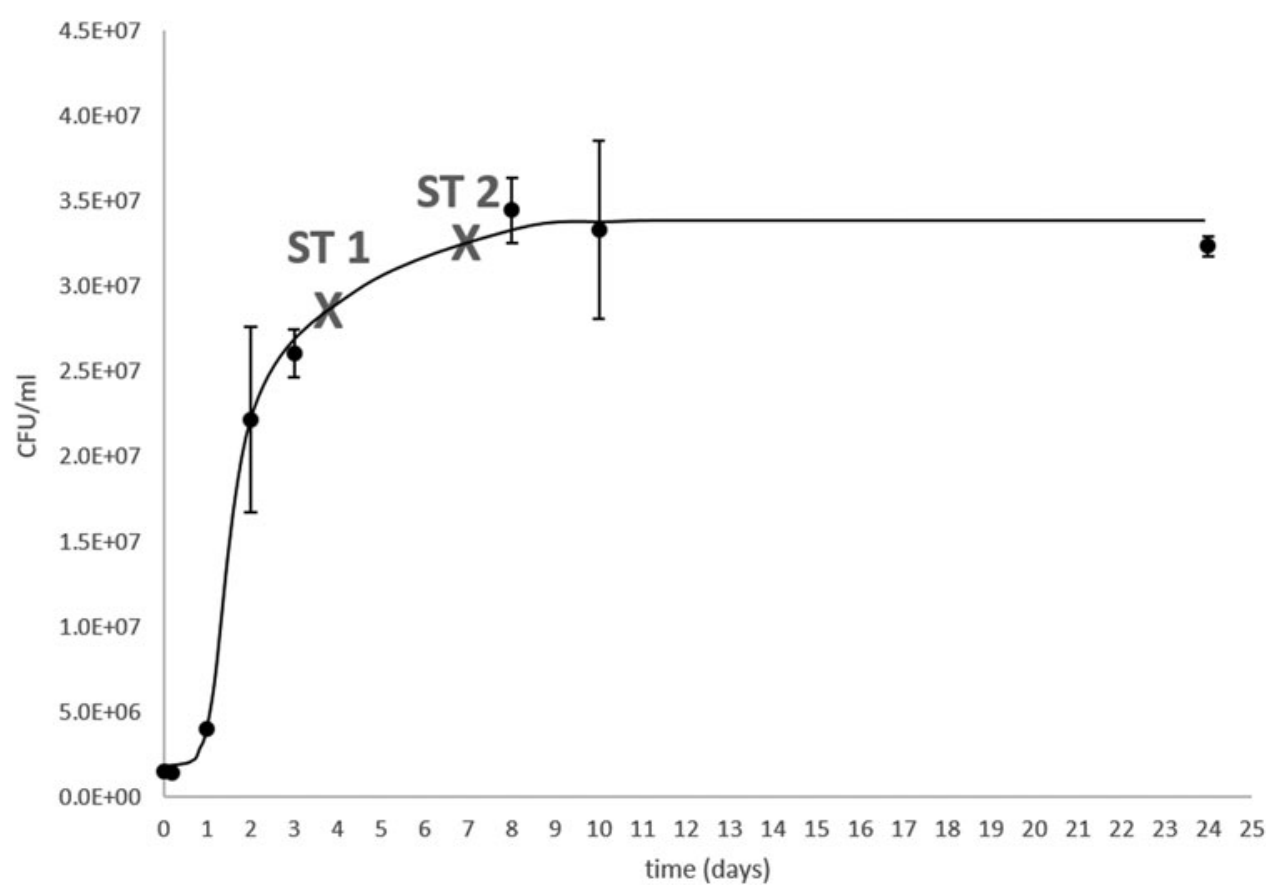

FIG. 1. Bacterial growth curve of Planococcus halocryophilus in DMSZ growth media $\# 92+10 \mathrm{wt} \% \mathrm{NaCl}$ at $25^{\circ} \mathrm{C}$. CFUs obtained as technical duplicates. Crosses mark the sampling times for inoculating of sample types ST 1 and ST 2. CFUs, colony forming units. 
Table 1. Eutectic Concentrations

and Temperatures, Ionic Strength, and Water Activities at $25^{\circ} \mathrm{C}$ FOR SAlt Solutions Used IN This STUdy

\begin{tabular}{|c|c|c|c|c|c|c|}
\hline & \multicolumn{2}{|c|}{$\begin{array}{c}\text { Eutectic } \\
\text { concentration }\end{array}$} & \multirow{2}{*}{$\frac{\begin{array}{c}\text { Ionic } \\
\text { strength }\end{array}}{\mathrm{mol} / \mathrm{L}}$} & \multirow{2}{*}{$\begin{array}{c}\text { Water } \\
\text { activity } \\
\text { at } 25^{\circ} \mathrm{C}\end{array}$} & \multicolumn{2}{|c|}{$\begin{array}{c}\text { Eutectic } \\
\text { temperature }\end{array}$} \\
\hline & $w t \%$ & $\mathrm{~mol} / \mathrm{L}$ & & & ${ }^{\circ} \mathrm{C}$ & $K$ \\
\hline & 2 & & & & -2 & 251 \\
\hline $\mathrm{MgCl}$ & $21^{\mathrm{a}}$ & 2.1 & 8. & & -33.5 & 239. \\
\hline $\mathrm{CaCl}_{2}$ & $30.2^{\mathrm{a}}$ & 3.90 & 11.70 & 0. & -50 & $223^{\mathrm{a}}$ \\
\hline $\mathrm{NaClO}$ & $52.6^{\mathrm{b}}$ & 9.06 & 9.06 & 0. & -34 & $239^{\mathrm{b}}$ \\
\hline $\mathrm{Mg}(\mathrm{ClO}$ & $44^{\mathrm{a}}$ & 3.52 & 10.56 & 0.56 & -57 & $216^{\mathrm{c}}$ \\
\hline $\mathrm{Ca}\left(\mathrm{ClO}_{4}\right)_{2}$ & $50.1^{\mathrm{d}}$ & 4.20 & 12.60 & 0.52 & -77.5 & 195. \\
\hline
\end{tabular}

${ }^{\mathrm{a}}$ Möhlmann and Thomsen (2011).

${ }^{\mathrm{b}}$ Hennings et al. (2013).

${ }^{\mathrm{c}}$ Stillman and Grimm (2011).

${ }^{\mathrm{d}}$ Pestova et al. (2005).

\subsection{Experiments in eutectic salt solutions}

In all experiments, $2 \mathrm{~mL}$ of the cell suspension (prepared as described in Section 2.1) was mixed with $8 \mathrm{~mL}$ of a salt solution resulting in $10 \mathrm{~mL}$ of sample solution with a eutectic salt concentration. The eutectic compositions of the investigated salts are listed in Table 1, together with the ionic strength, the water activity at $25^{\circ} \mathrm{C}$ calculated from the Pitzer equation (Pitzer, 1991) with Pitzer parameters taken from the work of Toner et al. (2015), and the eutectic temperature. All samples were prepared and analyzed as biological duplicates.

Before mixing cell suspensions and salt solutions, the suspensions were cooled to $4^{\circ} \mathrm{C}$ and the salt solutions to the respective experimental temperature. In addition, for testing whether $\mathrm{ClO}_{4}{ }^{-}$preconditioning of the cells has a positive effect on their survival in $\mathrm{ClO}_{4}{ }^{-}$containing samples, cell suspensions with either up to $10 \mathrm{wt} \% \mathrm{NaClO}_{4}$ or $5 \mathrm{wt} \% \mathrm{NaClO}_{4}+10 \mathrm{wt} \%$ $\mathrm{NaCl}$ were prepared and incubated for 7 days at $25^{\circ} \mathrm{C}$.

\subsection{Cell number quantification}

The concentration of viable cells in the samples was determined after specific time intervals via CFU counts, and, where necessary, samples were diluted in phosphate-buffered saline (PBS) containing $21 \mathrm{wt} \% \mathrm{NaCl}$ or $\mathrm{MgCl}_{2}$ to avoid osmotic bursting of cells. Highest values of $\mathrm{CFU} \mathrm{mL} \mathrm{mL}^{-1}$ were achieved when dilution was done with $\mathrm{NaCl}$-enriched PBS for samples containing $\mathrm{NaCl}, \mathrm{MgCl}_{2}, \mathrm{NaClO}_{4}$, or magnesium perchlorate $\left(\mathrm{Mg}\left(\mathrm{ClO}_{4}\right)_{2}\right)$, and $\mathrm{MgCl}_{2}$-enriched $\mathrm{PBS}$ for samples containing $\mathrm{CaCl}_{2}$ or calcium perchlorate $\left(\mathrm{Ca}\left(\mathrm{ClO}_{4}\right)_{2}\right)$. Because cell death occurred at higher temperatures during plating, especially in $\mathrm{Ca}^{2+}$ containing samples, plating for all experiments described in this study was carried out rapidly at cold temperatures. The $\mathrm{NaCl} / \mathrm{MgCl}_{2}$-enriched $\mathrm{PBS}$ was precooled to $-15^{\circ} \mathrm{C} /-30^{\circ} \mathrm{C}$ and agar plates to $4^{\circ} \mathrm{C}$.

\subsection{Freeze/thaw cycle experiments}

For investigating the effect of dissolved salts on cell survival when subjected to multiple freeze/thaw cycles, we incubated $P$. halocryophilus at $25^{\circ} \mathrm{C}$ for 1 week in six individual vials. Three of them contained $10 \mathrm{~mL}$ of DMSZ growth medium \#92 (with no additional $\mathrm{NaCl}$ ), while the other three samples contained additionally $10 \mathrm{wt} \% \mathrm{NaCl}$. After incubation, all samples where repeatedly frozen at $-50^{\circ} \mathrm{C}$, stored at this temperature between
1 and 3 days, and thawed at room temperature until the unfrozen sample reached $20^{\circ} \mathrm{C}$, which took $\sim 2 \mathrm{~h}$. After taking an aliquot from each sample for CFU determination, the samples were frozen again. These freeze/thaw cycles were repeated up to 70 times, and the survival was tested intermittently. The results for samples with the same growth media composition were averaged, and the standard deviation was calculated.

\section{Results}

\subsection{Microbial survival rates in chloride brines}

The survival rates of $P$. halocryophilus in eutectic $\mathrm{Cl}^{-}$samples were significantly increased when the samples were kept at lower temperatures (Fig. 2). For example, if $P$. halocryophilus was left in $\mathrm{NaCl}$ containing samples at room temperature, all cells died within 2 weeks, while their survival was substantially increased at $4^{\circ} \mathrm{C}$, and nearly no $\mathrm{CFU}$ reduction occurred at $-15^{\circ} \mathrm{C}$. Two samples of ST 2 were investigated for the $\mathrm{NaCl}$ system to confirm reproducibility. Samples of ST 2 had slightly higher starting cell numbers in all cases studied. However, survival rates of ST 1 and ST 2 samples were similar, although the curve for the $\mathrm{NaCl}$ ST 1 sample at $4^{\circ} \mathrm{C}$ had a steeper slope during the first 40 days but approached the slope of the ST 2 curves afterward.

The cell survival results for the $\mathrm{MgCl}_{2}$ containing samples were very similar to those of $\mathrm{NaCl}$, but at $-15^{\circ} \mathrm{C}$ and $-30^{\circ} \mathrm{C}$ there appears to be a slow reduction of surviving cells. The survival rates of $P$. halocryophilus in $\mathrm{CaCl}_{2}$ containing samples at $25^{\circ} \mathrm{C}$ and $4^{\circ} \mathrm{C}$ were significantly lower than those containing $\mathrm{NaCl}$ or $\mathrm{MgCl}_{2}$. In contrast, survival rates at subzero temperatures were comparable to the $\mathrm{MgCl}_{2}$ system, that is, cells were dying slower at these lower temperatures.

\subsection{Microbial survival rates in perchlorate brines}

The survival rates of $P$. halocryophilus in eutectic $\mathrm{ClO}_{4}^{-}$ samples (Fig. 3) were orders of magnitude lower than in $\mathrm{Cl}^{-}$ samples (Fig. 2). Although survivability at lower temperatures in $\mathrm{NaClO}_{4}$ samples increased, the survival rate was generally so low that even at $-30^{\circ} \mathrm{C}$, few cells survived for only 1 day (Fig. 3A, B). For $\mathrm{Mg}\left(\mathrm{ClO}_{4}\right)_{2}$ and $\mathrm{Ca}\left(\mathrm{ClO}_{4}\right)_{2}$ containing samples, survival was even lower, where CFU detection was only possible for samples stored at $-30^{\circ} \mathrm{C}$, and none was detected for samples kept at higher temperatures.

We increased the $\mathrm{NaClO}_{4}$ concentration in the growth media to determine whether $\mathrm{ClO}_{4}{ }^{-}$preconditioning of $P$. halocryophilus could enhance survival in eutectic $\mathrm{ClO}_{4}^{-}$samples. It was found that $P$. halocryophilus can grow in the presence of up to at least 10 wt $\% \mathrm{NaClO}_{4}$ (with no additional $\mathrm{NaCl}$ in the growth medium) or up to $10 \mathrm{wt} \% \mathrm{NaCl}+5 \mathrm{wt} \% \mathrm{NaClO}_{4}$. However, cell growth under these conditions was markedly slower than in $\mathrm{ClO}_{4}{ }^{-}$-free medium. Thus, for the preconditioning experiments we used cells preconditioned with $8 \mathrm{wt} \% \mathrm{NaClO}_{4}$ or with $10 \mathrm{wt} \%$ $\mathrm{NaCl}+3 \mathrm{wt} \% \mathrm{NaClO}_{4}$ (Fig. 3B). Nevertheless, in these cases, cells grew slower than in the experiments with $10 \mathrm{wt} \% \mathrm{NaCl}$ in the growth media, which resulted in a lower starting cell number.

Due to the slower growth rates in $\mathrm{ClO}_{4}{ }^{-}$containing media, the cells should still be in the exponential growth phase after 7 days of incubation. We found that changing the preconditioning salt from $\mathrm{NaCl}$ to $\mathrm{NaClO}_{4}$ did not increase the survivability in $\mathrm{ClO}_{4}{ }^{-}$containing samples. However, increasing the total salt concentration by adding $3 \mathrm{wt} \% \mathrm{NaClO}_{4}$ on $10 \mathrm{wt} \%$ $\mathrm{NaCl}$ resulted in a slight increase in survival. Cells in these 

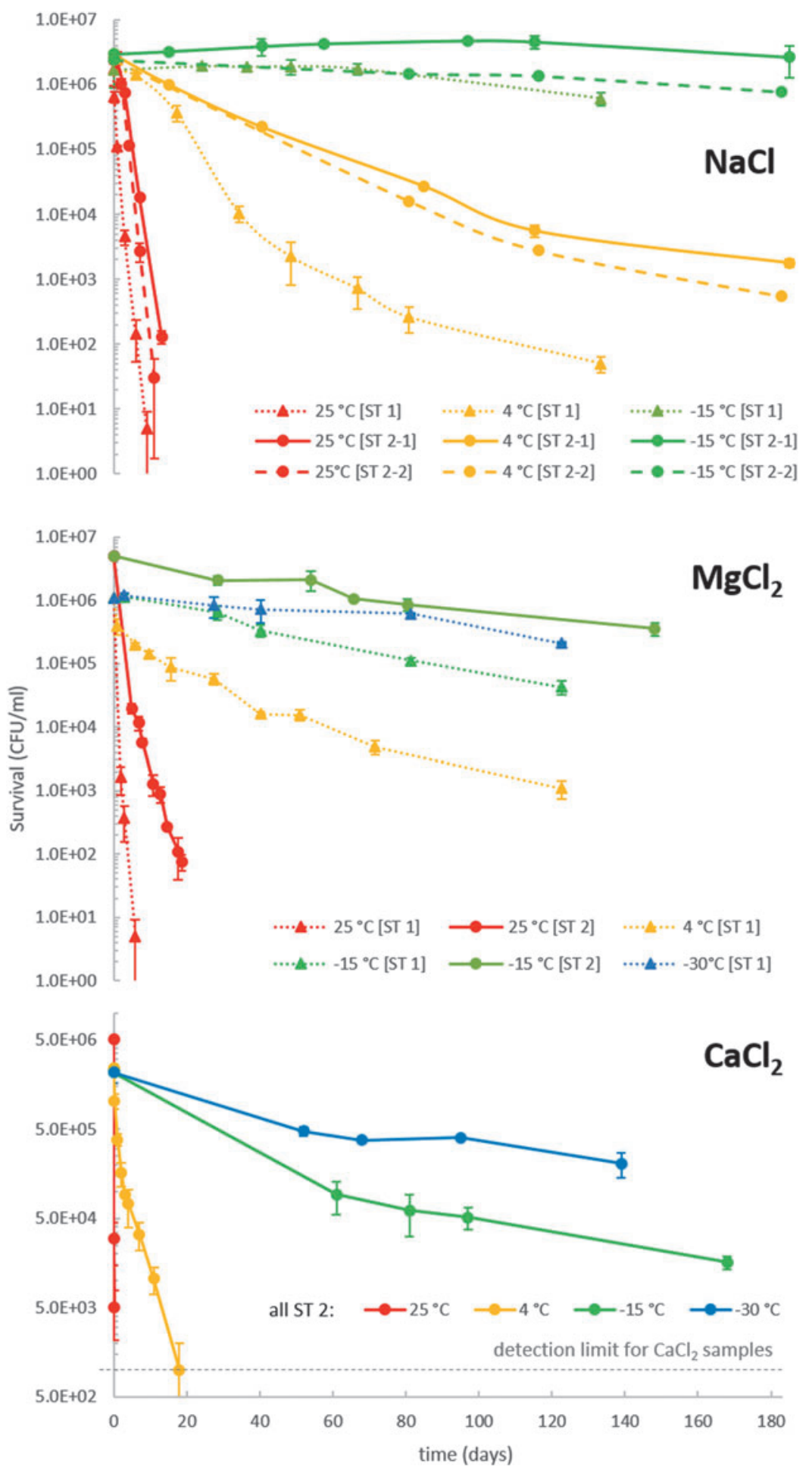

FIG. 2. Survival rates of $P$. halocryophilus in eutectic $\mathrm{Cl}^{-}$samples. Initial cell cultures were incubated for 4 days (ST 1) or 7 days (ST 2) at $25^{\circ} \mathrm{C}$ in growth medium containing $10 \mathrm{wt} \% \mathrm{NaCl}$ before mixing them with the salt solution. CFUs were obtained as biological duplicates. Detection limit for $\mathrm{CaCl}_{2}$ containing samples at $10^{3} \mathrm{CFU} / \mathrm{mL}$ results from the dilution factor of 3 that is necessary to decrease the $\mathrm{Ca}^{2+}$ concentration on the agar plate sufficiently for colony growth to occur. samples doubled their maximum survival time from $\sim 1$ day in samples containing either $8 \mathrm{wt} \% \mathrm{NaClO}_{4}$ or $10 \mathrm{wt} \% \mathrm{NaCl}$ to 2 days in samples containing $3 \mathrm{wt} \% \mathrm{NaClO}_{4}+10 \mathrm{wt} \% \mathrm{NaCl}$.

\subsection{Arrhenius plot}

For a better comparison of the temperature dependences of cell survival in different $\mathrm{Cl}^{-}$and $\mathrm{ClO}_{4}{ }^{-}$containing samples, the data were plotted as an Arrhenius-type graph, with the slopes of the survival rate-fitted lines for all $\mathrm{Cl}^{-}$and $\mathrm{NaClO}_{4}$ containing samples (values for same salt/temperature combinations were averaged) plotted logarithmically against the temperature of the sample (Fig. 4A). As the slope (S) of these curves is the crucial parameter for evaluating the extent to which survival is increased with lowering temperature, the slope values for each curve were plotted as well (Fig. 4B).

The slopes for the $\mathrm{Cl}^{-}$containing samples, especially for $\mathrm{MgCl}_{2}$ and $\mathrm{CaCl}_{2}$, flatten below death rate constants of about 0.1 day $^{-1}$. However, it has to be kept in mind that the death rates are on a logarithmic scale, and therefore, the 

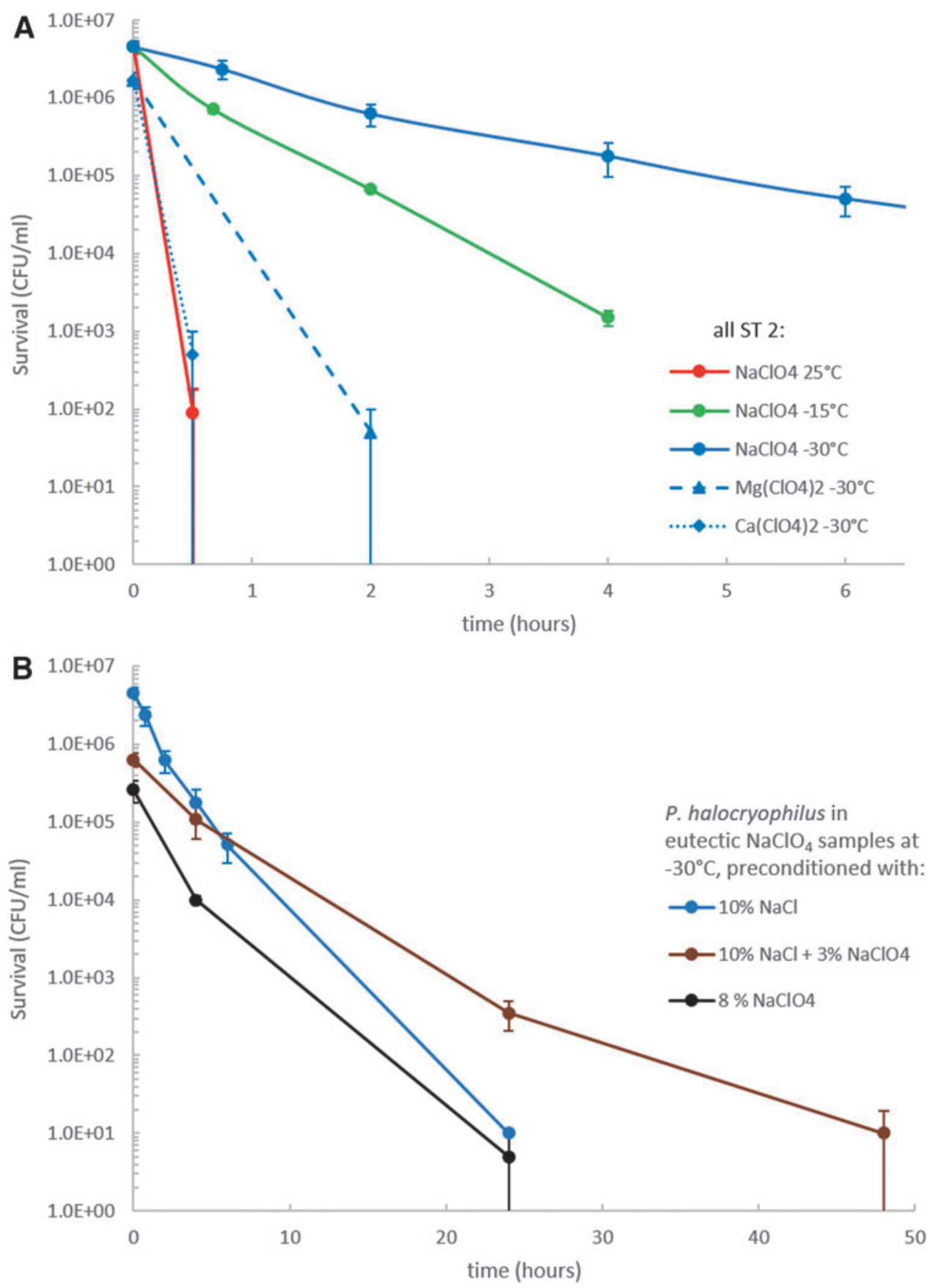

FIG. 3. (A) Survival rates of $P$. halocryophilus in $\mathrm{ClO}_{4}{ }^{-}$samples. Initial cell cultures were incubated for 7 days at $25^{\circ} \mathrm{C}$ in growth medium containing $10 \mathrm{wt} \% \mathrm{NaCl}$ before mixing them with the salt solution (B). Effects of different preconditioning methods at $-30^{\circ} \mathrm{C}$. Before mixing them with the salt solution, the initial cell cultures were incubated for 7 days at $25^{\circ} \mathrm{C}$ in growth medium containing salts as indicated in the figure legend. CFUs were obtained in biological duplicates.

flattening might only be the result of approaching a nonlethal state, that is, a death rate of zero. Therefore, only the steeper slops of the curves toward higher temperatures were compared, as given in Figure 4B.

\subsection{Microbial survival rates during freeze/thaw cycles}

P. halocryophilus survived repeated freeze/thaw cycles more readily if the growth medium contained additional $\mathrm{NaCl}$. Without $\mathrm{NaCl}$, the $\mathrm{CFU}$ reduction is $20 \%$ per freeze/ thaw cycle, whereas an addition of $10 \mathrm{wt} \% \mathrm{NaCl}$ lowered the death rate to $7 \%$ per freeze/thaw cycle (Fig. 5). Cells in the salt-free samples survived up to 70 freeze/thaw cycles, while extrapolation of the death rate curve for the samples containing $10 \mathrm{wt} \% \mathrm{NaCl}$ reveals that cells in these samples could survive up to $\sim 200$ freeze/thaw cycles.

\section{Discussion}

We have shown that survival of $P$. halocryophilus is significantly lower in eutectic $\mathrm{ClO}_{4}{ }^{-}$samples than in $\mathrm{Cl}^{-}$containing samples at all investigated temperatures, although ionic strength 

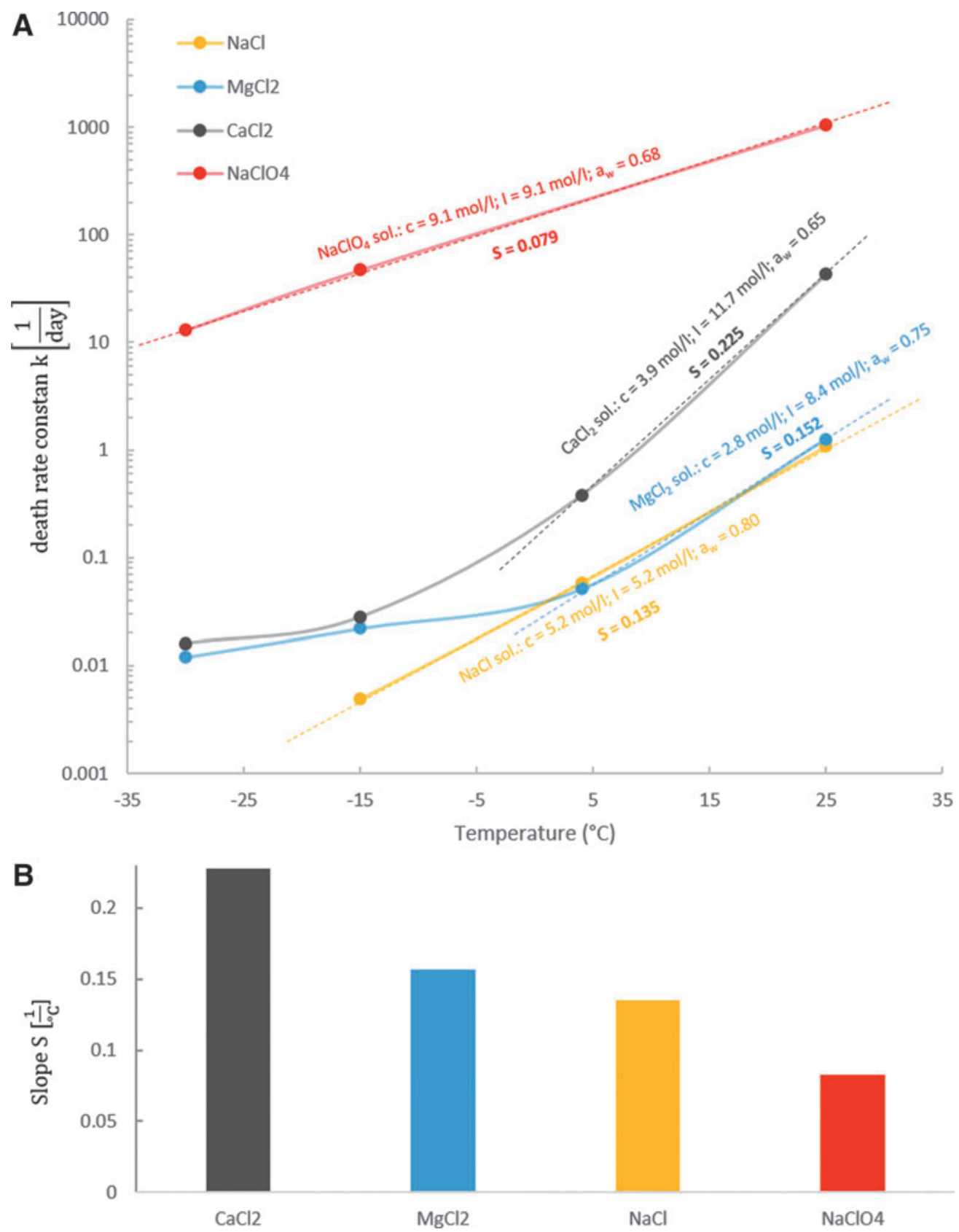

FIG. 4. (A) Arrhenius-type plot for all $\mathrm{Cl}^{-}$samples and $\mathrm{NaClO}_{4}$, including slopes (S) for linear parts of the curves and molar concentrations (c), water activities $\left(\mathrm{a}_{\mathrm{w}}\right)$, and ionic strengths (I) for all samples. (B) Slopes (S) of the steeper curve parts plotted as bar charts.

and water activities at $25^{\circ} \mathrm{C}$ are similar, for example, for $\mathrm{CaCl}_{2}$ and $\mathrm{NaClO}_{4}$ samples (Table 1 and Fig. 4A). Moreover, the water activity should not change markedly when lowering the temperature since it has been shown to remain reasonably constant at subzero temperatures for solutions containing $\mathrm{Cl}^{-}$ (Fontan and Chirife, 1981) and $\mathrm{ClO}_{4}^{-}$(Toner and Catling, 2016). Furthermore, the oxidizing ability of $\mathrm{ClO}_{4}{ }^{-}$is negligible in solutions at these low temperatures (Brown and $\mathrm{Gu}, 2006$ ). Thus, other ion-specific properties must be responsible for the differences in the inhibitory effects of the $\mathrm{ClO}_{4}{ }^{-}$and $\mathrm{Cl}^{-}$ containing samples.

In addition, we demonstrated that the survival of $P$. halocryophilus cells in eutectic $\mathrm{Cl}^{-}$and $\mathrm{ClO}_{4}^{-}$samples in- creases systematically with decreasing temperatures. The Arrhenius plot (Fig. 4) indicates that this correlation is more significant in $\mathrm{Cl}^{-}$containing samples. The slope for the $\mathrm{CaCl}_{2}$ containing samples $\left(0.225^{\circ} \mathrm{C}^{-1}\right)$ is more than 2.5 -fold steeper than for the $\mathrm{NaClO}_{4}$ containing samples $\left(0.079^{\circ} \mathrm{C}^{-1}\right)$, which means that survivability in the $\mathrm{CaCl}_{2}$ samples is increased by lowering temperature to a significantly higher extant than in the $\mathrm{NaClO}_{4}$ samples. The slopes for $\mathrm{MgCl}_{2}\left(0.152^{\circ} \mathrm{C}^{-1}\right)$ and $\mathrm{NaCl}\left(0.135^{\circ} \mathrm{C}^{-1}\right)$ containing samples lie between those of $\mathrm{NaClO}_{4}$ and $\mathrm{CaCl}_{2}$.

The slow decrease of the death rate constant in the Na$\mathrm{ClO}_{4}$ containing samples with decreasing temperature is caused by the normal temperature dependence of all 
FIG. 5. Survivability of $P$. halocryophilus during freeze/thaw cycles. Cells were incubated for 7 days at $25^{\circ} \mathrm{C}$ in growth medium containing either no additional salt (black circles) or $10 \mathrm{wt} \% \mathrm{NaCl}$ (gray triangles) before subjecting them to freeze/thaw cycles. CFUs obtained from biological triplicates.

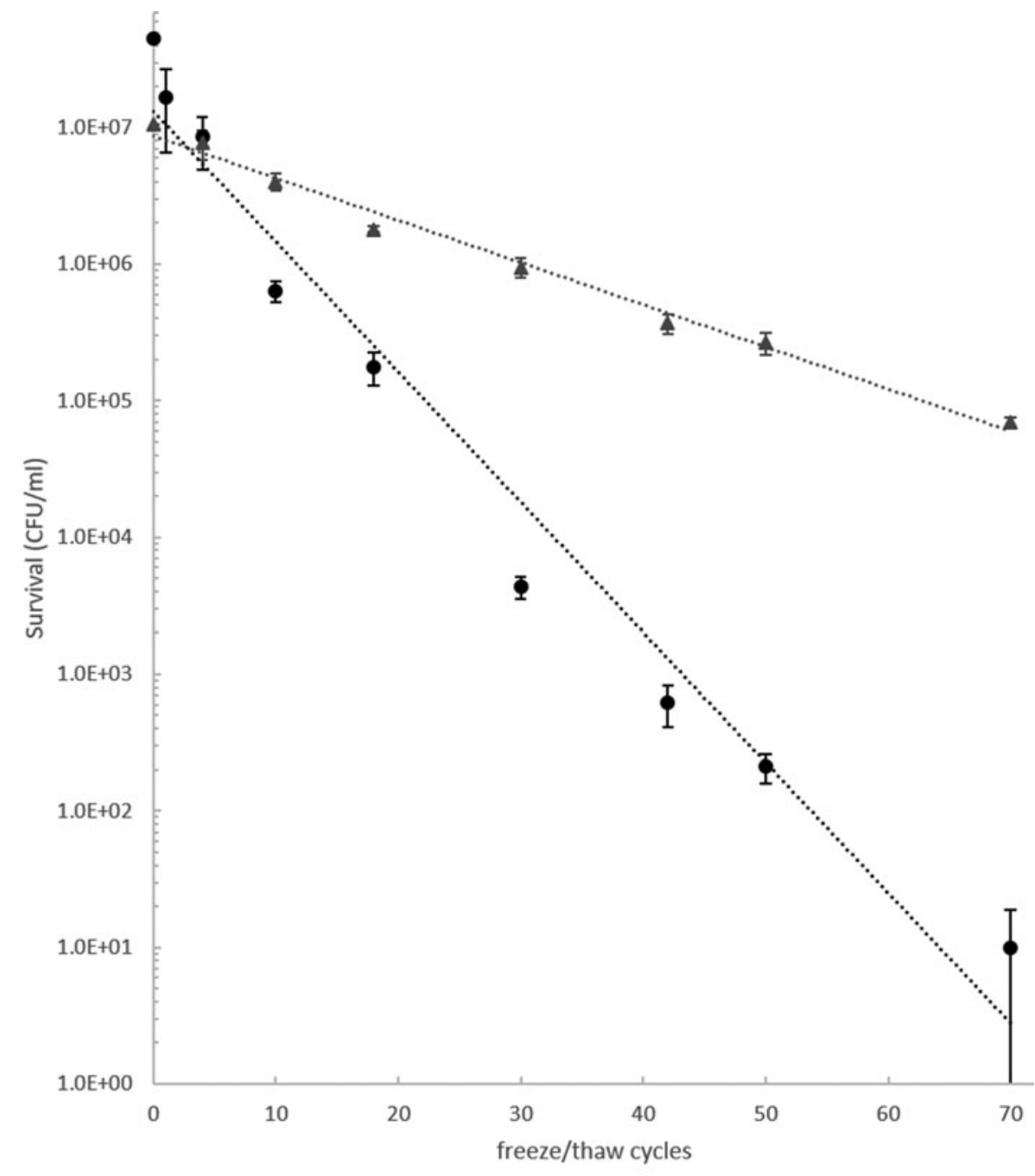

- P. halocryophilus in medium with no additional $\mathrm{NaCl} \boldsymbol{\Delta}$ P. halocryophilus in medium containing $10 \mathrm{wt} \% \mathrm{NaCl}$ chemical reactions (including cell damaging reactions) described by the Arrhenius equation. The steeper slopes for the $\mathrm{Cl}^{-}$samples indicate an additional effect on the decrease of death rates with lowering the temperature.

We propose that the main reason for this difference in the temperature dependence of the cell survival in $\mathrm{Cl}^{-}$and $\mathrm{ClO}_{4}{ }^{-}$ containing samples is the increase of size and stability of hydration spheres around the ions in the $\mathrm{Cl}^{-}$brines at lower temperatures. Previous studies have shown that with decreasing temperatures the hydration number around cations such as $\mathrm{Ca}^{2+}$ increases (Zavitsas, 2005) and that the first hydration sphere around $\mathrm{Na}^{+}$in $\mathrm{NaCl}$ solutions becomes more rigid (Gallo et al., 2011). Furthermore, X-ray and neutron diffraction studies have shown that a decrease in temperature results in the first hydration shell of $\mathrm{Cl}^{-}$ions becoming gradually more structured and a second hydration sphere forming (Yamaguchi et al., 1995). Data from the method of integral equations reveal a strengthening of the hydrogen bonding between $\mathrm{Cl}^{-}$and water molecules in the first hydration shell at lower temperatures (Oparin et al., 2002).

These results demonstrate that lowering the temperature in $\mathrm{Cl}^{-}$containing samples increases the stability and size of hydration spheres around the dissolved ions, known to reduce the permeability of ions through cell membranes (Degrève et al., 1996; Jahnen-Dechent and Ketteler, 2012). Hence, we conclude that a reduced ion permeability caused by larger and more stable hydration spheres minimizes the toxicity of the extracellular high ion concentration. Therefore, cell survivability in low-temperature $\mathrm{Cl}^{-}$brines is increased over the extent of the normal Arrhenius-like temperature dependence.

In contrast to cations and $\mathrm{Cl}^{-}$ions, $\mathrm{ClO}_{4}{ }^{-}$ions do not tend to form stable hydration shells (Neilson et al., 1985; LindqvistReis et al., 1998). The reason for the small size and low stability of hydration shells around $\mathrm{ClO}_{4}{ }^{-}$is its large ionic radius and its low electrical charge with an even distribution over the entire anion (Brown and $\mathrm{Gu}, 2006$ ) resulting in weak hydrogen bonds and one of the lowest hydration energies of common inorganic anions (Moyer and Bonnesen, 1979). The low tendency of $\mathrm{ClO}_{4}{ }^{-}$ions to form stable hydration spheres at any temperature presumably correlates with a constant cell membrane permeability and is a reasonable explanation for the observed low survival rate increase in $\mathrm{ClO}_{4}{ }^{-}$containing samples with lower temperatures.

Finally, the higher membrane permeability at all investigated temperatures explains the general low survivability of cells in $\mathrm{ClO}_{4}^{-}$verses $\mathrm{Cl}^{-}$containing samples. However, several other structural factors may play a significant role as well, for example, the formation of chloro-complexes in $\mathrm{CaCl}_{2}$ 
containing samples (Phutela and Pitzer, 1983; Wang et al., 2016), ion pair formations (Fleissner et al., 1993; Smirnov et al., 1998), molecular mimicry (Cianchetta et al., 2010), or the reported formation of a crust around $P$. halocryophilus cells at low temperatures, consisting of peptidoglycan, choline, and calcium carbonate (Mykytczuk et al., 2016) that might provide protection against $\mathrm{Cl}^{-}$but not $\mathrm{ClO}_{4}{ }^{-}$.

The freeze/thaw experiments have shown that the survivability of cells during freezing and thawing processes increases when $\mathrm{NaCl}$ is present. Studies have argued that the formation of large water crystals during freezing might be destructive to cell membranes and might even grow larger during thawing due to migratory recrystallization (Mazur, 1960). Greater amounts of large water crystals should only form in the salt-free samples, because in the salt-rich samples, pure water crystals are formed during freezing only until the solution under the ice layer reaches the eutectic composition. After that point, eutectic freezing results in very small water ice and salt hydrate particles, which potentially could be physically less harmful to the cells.

Another lethal effect during the freezing process might be the osmotic shock resulting from the increasing solute concentration in the remaining liquid solution (Harrison, 1956). It is reasonable to assume that the decreased water activity, as a result of the enhanced solute concentration in the growth media during the freezing process, is less harmful to bacteria that were already preconditioned with $10 \mathrm{wt} \% \mathrm{NaCl}$ during incubation. Furthermore, studies have shown that a heat or cold shock treatment of Deinococcus radiodurans cells increases their survivability against freeze/thaw cycles (Airo et al., 2004), hence an exposure to higher salt concentrations may result in a similar stress response in $P$. halocryophilus and a higher tolerance against freeze/thaw cycling. The beneficial effect of $\mathrm{NaCl}$ during the freeze/thaw process has been described in previous studies (e.g., Calcott and Rose, 1982).

In contrast, other studies have shown the opposite trend, that the presence of $\mathrm{NaCl}$ decreases the percent of surviving bacteria during freeze/thaw cycles (Postgate and Hunter, 1961; Nelson and Parkinson, 1979). However, these bacteria are not known to be halotolerant and therefore might suffer more under increased osmotic stress than $P$. halocryophilus does. In the future, freeze/thaw experiments with halophilic microorganisms such as $P$. halocryophilus should also include other types of salts in the growth medium to test their influence on cell survivability in comparison with $\mathrm{NaCl}$.

On Mars, $\mathrm{NaCl}$ has been detected globally, and especially at high levels by remote sensing in the Southern Highlands (Osterloo et al., 2008). Perchlorates have been detected at the Phoenix Lander and the Curiosity Rover sites and are likely global in extent (Clark and Kounaves, 2016). These salts have also been suggested to be part of the brines associated with the recurrent slope lineae (RSL) (Ojha et al., 2015). However, more recent studies have argued that only small amounts of water might be present within the RSL (Edwards and Piqueux, 2016) and that the darkening of the RSL might only be a result of a rewetting process of former flows of salty water (Heinz et al., 2016). Furthermore, it has also been suggested that RSL may be the result of granular flows where water plays no, or only a subordinate, role (Dundas et al., 2017).

However, in general, the ubiquitous presence of hygroscopic salts and of water in the form of ice on the poles or in the subsurface or as gas in the atmosphere makes the existence of cold, highly concentrated brines conceivable. Such brines could develop through deliquescence or at salt-ice contacts (Fischer et al., 2014), being temporally stable at the surface of Mars and perhaps permanently stable in the subsurface as briny groundwater (Burt and Knauth, 2003; Martínez and Renno, 2013).

Our data reveal that microorganisms resident in such brines could survive significantly longer at subzero temperatures than previously thought, and they might even thrive in slightly diluted brines as has been shown for $P$. halocryophilus in a $19 \mathrm{wt} \% \mathrm{NaCl}$ solution (Mykytczuk et al., 2012). As temperatures on Mars change throughout the day and the seasons, it is conceivable that temperatures drop temporally below the eutectic temperature of the brine. Our freeze/thaw experiments demonstrate that the freezing and thawing of cells in eutectic brines would be less lethal than freezing and thawing in saltfree water.

\section{Conclusion}

We have shown enhanced microbial survival in subzero eutectic $\mathrm{Cl}^{-}$brines compared with their warmer analogues. Based on the results, the best hypothesis is that the increase in size and stability of hydration shells around ions at lower temperatures reduces osmotic and chaotropic stress factors for microbial organisms.

Although $P$. halocryophilus grew even in the presence of $10 \mathrm{wt} \% \mathrm{NaClO}_{4}$, higher $\mathrm{ClO}_{4}{ }^{-}$concentrations lower survival rates significantly even at subzero temperatures. It appears that the decreased capability of $\mathrm{ClO}_{4}{ }^{-}$ions to form stable hydration spheres causes the high toxicity of eutectic $\mathrm{ClO}_{4}{ }^{-}$solutions and the lower temperature dependence of cell survival compared with $\mathrm{Cl}^{-}$brines. Furthermore, we have shown that the presence of salts such as $\mathrm{NaCl}$ increases the survivability during freeze/ thaw processes. This has broad implications for the habitability of some extreme environments on Earth and the potential habitability of Mars.

\section{Acknowledgments}

We thank Lyle Whyte for helping to improve the article. This project was funded by the European Research Council Advanced Grant "Habitability of Martian Environments" (HOME, no. 339231). All of the numerical data for this article are provided in the figures and are also available in tabular form from the authors on request (j.heinz@tu-berlin.de).

\section{Author Disclosure Statement}

No competing financial interests exist.

\section{References}

Airo, A., Chan, S.L., Martinez, Z., Platt, M.O., and Trent, J.D. (2004) Heat shock and cold shock in Deinococcus radiodurans. Cell Biochem Biophys 40:277-288.

Bakermans, C. (2012) Psychrophiles: life in the cold. In Extremophiles: Microbiology and Biotechnology, edited by R. Anitoris, Horizon Scientific Press, Hethersett, United Kingdom, pp 53-76.

Brown, G.M. and Gu, B. (2006) The chemistry of perchlorate in the environment. In Perchlorate: Environmental Occurrence, Interactions and Treatment, edited by B. Gu and J.D. Coates, Springer US, Boston, MA, pp 17-47.

Burt, D.M. and Knauth, L.P. (2003) Electrically conducting, Ca-rich brines, rather than water, expected in the Martian subsurface. J Geophys Res 108:8026. 
Calcott, P.H. and Rose, A.H. (1982) Freeze-thaw and cold-shock resistance of saccharomyces cerevisiae as affected by plasma membrane lipid composition. Microbiology 128:549-555.

Cameron, R.E., Morelli, F.A., and Randall, L.P. (1972) Aerial, aquatic, and soil microbiology of Don Juan Pond, Antarctica. Antarct J US 7:254-258.

Chattopadhyay, M.K., Raghu, G., Sharma, Y.V.R.K., Biju, A.R., Rajasekharan, M.V., and Shivaji, S. (2011) Increase in oxidative stress at low temperature in an Antarctic bacterium. Curr Microbiol 62:544-546.

Chin, J.P., Megaw, J., Magill, C.L., Nowotarski, K., Williams, J.P., Bhaganna, P., Linton, M., Patterson, M.F., Underwood, G.J.C., Mswaka, A.Y., and Hallsworth, J.E. (2010) Solutes determine the temperature windows for microbial survival and growth. Proc Natl Acad Sci U S A 107:7835-7840.

Cianchetta, S., Di Bernardo, J., Romeo, G., and Rhoden, K.J. (2010) Perchlorate transport and inhibition of the sodium iodide symporter measured with the yellow fluorescent protein variant YFP-H148Q/I152L. Toxicol Appl Pharmacol 243:372-380.

Clark, B.C. and Kounaves, S.P. (2016), Evidence for the distribution of perchlorates on Mars. Int J Astrobiol 15:311-318.

Collins, M.A. and Buick, R.K. (1989) Effect of temperature on the spoilage of stored peas by Rhodotorula glutinis. Food Microbiol 6:135-141.

Csonka, L.N. (1989) Physiological and genetic responses of bacteria to osmotic stress. Microbiol Rev 53:121-147.

Davila, A.F. and Schulze-Makuch, D. (2016) The last possible outposts of life on Mars. Astrobiology 16:159-168.

Davila, A.F., Gómez-Silva, B., de los Rios, Asunción, Ascaso, C., Olivares, H., McKay, C.P., and Wierzchos, J. (2008) Facilitation of endolithic microbial survival in the hyperarid core of the Atacama Desert by mineral deliquescence. $J$ Geophys Res 113; doi: 10.1029/2007JG000561.

de Vera, J.-P.P., Schulze-Makuch, D., Khan, A., Lorek, A., Koncz, A., Möhlmann, D., and Spohn, T. (2014) Adaptation of an Antarctic lichen to Martian niche conditions can occur within 34 days. Planetary Space Sci 98:182-190.

Degrève, L., Vechi, S.M., and Junior, C.Q. (1996) The hydration structure of the $\mathrm{Na}+$ and $\mathrm{K}+$ ions and the selectivity of their ionic channels. Biochim Biophys Acta Bioenerg 1274:149-156.

Denich, T., Beaudette, L., Lee, H., and Trevors, J. (2003) Effect of selected environmental and physico-chemical factors on bacterial cytoplasmic membranes. J Microbiol Methods 52:149-182.

Dickson, J.L., Head, J.W., Levy, J.S., and Marchant, D.R. (2013) Don Juan Pond, Antarctica: near-surface $\mathrm{CaCl}(2)$ brine feeding Earth's most saline lake and implications for Mars. Sci Rep 3:1166.

Dundas, C.M., McEwen, A.S., Chojnacki, M., Milazzo, M.P., Byrne, S., McElwaine, J.N., and Urso, A. (2017) Granular flows at recurring slope lineae on Mars indicate a limited role for liquid water. Nat Geosci 10:903-907.

Edwards, C.S. and Piqueux, S. (2016) The water content of recurring slope lineae on Mars. Geophys Res Lett 43: 8912-8919.

Fischer, E., Martínez, G.M., Elliott, H.M., and Rennó, N.O. (2014) Experimental evidence for the formation of liquid saline water on Mars. Geophys Res Lett 41:4456-4462.

Fleissner, G., Hallbrucker, A., and Mayer, E. (1993) Increasing contact ion pairing in the supercooled and glassy states of "dilute" aqueous magnesium, calcium, and strontium nitrate solution: implications for biomolecules. J Phys Chem 97:4806-4814.

Fontan, C.F. and Chirife, J. (1981) The evaluation of water activity in aqueous solutions from freezing point depression. Int J Food Sci Technol 16:21-30.
Gallo, P., Corradini, D., and Rovere, M. (2011) Ion hydration and structural properties of water in aqueous solutions at normal and supercooled conditions: a test of the structure making and breaking concept. Phys Chem Chem Phys 13: 19814-19822.

Gerba, C.P. (1984) Applied and theoretical aspects of virus adsorption to surfaces. Adv Appl Microbiol 30:133-168.

Gilbert, J.A., Davies, P.L., and Laybourn-Parry, J. (2005) A hyperactive, $\mathrm{Ca} 2+-$ dependent antifreeze protein in an Antarctic bacterium. FEMS Microbiol Lett 245:67-72.

Gilichinsky, D., Rivkina, E., Shcherbakova, V., Laurinavichuis, K., and Tiedje, J. (2003) Supercooled water brines within permafrost-an unknown ecological niche for microorganisms: a model for astrobiology. Astrobiology 3:331-341.

Gounot, A.-M. (1986) Psychrophilic and psychrotrophic microorganisms. Experientia 42:1192-1197.

Harrison, A.P. (1956) Causes of death of bacteria in frozen suspensions. Antonie van Leeuwenhoek 22:407-418.

Hecht, M.H., Kounaves, S.P., Quinn, R.C., West, S.J., Young, S M M, Ming, D.W., Catling, D.C., Clark, B.C., Boynton, W.V., Hoffman, J., Deflores, L.P., Gospodinova, K., Kapit, J., and Smith, P.H. (2009) Detection of perchlorate and the soluble chemistry of martian soil at the Phoenix lander site. Science 325:64-67.

Heinz, J., Schulze-Makuch, D., and Kounaves, S.P. (2016) Deliquescence-induced wetting and RSL-like darkening of a Mars analogue soil containing various perchlorate and chloride salts. Geophys Res Lett 43:4880-4884.

Hennings, E., Heinz, J., Schmidt, H., and Voigt, W. (2013) Freezing and hydrate formation in aqueous sodium perchlorate solutions. Z Anorg Allg Chem 639:922-927.

Hoover, R.B. and Pikuta, E. (2010) Psychrophilic and psychrotolerant microbial extremophiles in Polar environments. In Polar Microbiology: The Ecology, Biodiversity, and Bioremediation Potential of Microorganisms in Extremely Cold Environments, edited by A.K. Bej, J. Aislabie, and R.M. Atlas, CRC Press, Boca Raton, FL, pp 115-156.

Jahnen-Dechent, W. and Ketteler, M. (2012) Magnesium basics. Clin Kidney J 5:i3-i14.

Jia, Z., DeLuca, C.I., Chao, H., and Davies, P.L. (1996) Structural basis for the binding of a globular antifreeze protein to ice. Nature 384:285-288.

Kounaves, S.P., Hecht, M.H., Kapit, J., Gospodinova, K., DeFlores, L., Quinn, R.C., Boynton, W.V., Clark, B.C., Catling, D.C., Hredzak, P., Ming, D.W., Moore, Q., Shusterman, J., Stroble, S., West, S.J., and Young, S.M.M. (2010) Wet chemistry experiments on the 2007 Phoenix Mars Scout Lander mission: data analysis and results. J Geophys Res 115; doi: 10.1029/2009JE003424.

Kuhlmann, A.U., Hoffmann, T., Bursy, J., Jebbar, M., and Bremer, E. (2011) Ectoine and hydroxyectoine as protectants against osmotic and cold stress: uptake through the SigB-controlled betaine-choline-carnitine transporter-type carrier EctT from Virgibacillus pantothenticus. J Bacteriol 193:4699-4708.

Lindqvist-Reis, P., Muñoz-Páez, A., Díaz-Moreno, S., Pattanaik, S., Persson, I., and Sandström, M. (1998) The structure of the hydrated gallium(III), indium(III), and chromium(III) ions in aqueous solution. A large angle X-ray scattering and EXAFS study. Inorg Chem 37:6675-6683.

Maki, S., Yoneta, M., and Takada, Y. (2006) Two isocitrate dehydrogenases from a psychrophilic bacterium, Colwellia psychrerythraea. Extremophiles 10:237-249.

Martínez, G.M. and Renno, N.O. (2013) Water and brines on Mars: current evidence and implications for MSL. Space Sci Rev 175:29-51. 
Mazur, P. (1960) Physical factors implicated in the death of microorganisms at subzero temperatures. Ann N Y Acad Sci 85:610-629.

Miteva, V., Sowers, T., and Brenchley, J. (2007) Production of $\mathrm{N}_{2} \mathrm{O}$ by ammonia oxidizing bacteria at subfreezing temperatures as a model for assessing the $\mathrm{N}_{2} \mathrm{O}$ Anomalies in the Vostok Ice Core. Geomicrobiol J 24:451-459.

Möhlmann, D. and Thomsen, K. (2011) Properties of cryobrines on Mars. Icarus 212:123-130.

Moyer, B. and Bonnesen, P.V. (1979) Physical factors in anion separation. In Supramolecular Chemistry of Anions, edited by A. Bianchi, K. Bowman-James, and E. Garcia-Espana, Wiley-VCH, Inc., New York, pp 1-44.

Mykytczuk, N.C.S., Wilhelm, R.C., and Whyte, L.G. (2012) Planococcus halocryophilus sp. nov., an extreme sub-zero species from high Arctic permafrost. Int J Syst Evol Microbiol 62:1937-1944.

Mykytczuk, N.C.S., Foote, S.J., Omelon, C.R., Southam, G., Greer, C.W., and Whyte, L.G. (2013) Bacterial growth at $-15^{\circ} \mathrm{C}$; molecular insights from the permafrost bacterium Planococcus halocryophilus Or1. ISME J 7:1211-1226.

Mykytczuk, N.C.S., Lawrence, J.R., Omelon, C.R., Southam, G., and Whyte, L.G. (2016) Microscopic characterization of the bacterial cell envelope of Planococcus halocryophilus Or1 during subzero growth at $-15^{\circ} \mathrm{C}$. Polar Biol 39: 701-712.

Neilson, G.W., Schiöberg, D., and Luck, W. (1985) The structure around the perchlorate ion in concentrated aqueous solutions. Chem Phys Lett 122:475-479.

Nelson, L.M. and Parkinson, D. (1979) Effect of freezing and thawing on survival of three bacterial isolates from an arctic soil. Can J Microbiol 24:1468-1474.

Ojha, L., Wilhelm, M.B., Murchie, S.L., McEwen, A.S., Wray, J.J., Hanley, J., Massé, M., and Chojnacki, M. (2015) Spectral evidence for hydrated salts in recurring slope lineae on Mars. Nat Geosci 8:829-832.

Oparin, R., Fedotova, M., and Trostin, V.N. (2002) Relationship between the structural state of water and the character of ion hydration in concentrated 1:1 aqueous solutions of electrolytes in extreme conditions. J Struct Chem 43:467-472.

Osterloo, M.M., Hamilton, V.E., Bandfield, J.L., Glotch, T.D., Baldridge, A.M., Christensen, P.R., Tornabene, L.L., and Anderson, F.S. (2008) Chloride-bearing materials in the Southern Highlands of Mars. Science 21:1651-1654.

Pestova, O.N., Myund, L.A., Khripun, M.K., and Prigaro, A.V. (2005) Polythermal study of the systems $\mathrm{M}(\mathrm{ClO} 4) 2-\mathrm{H} 2 \mathrm{O}$ ( $\mathrm{M} 2+=$ $\mathrm{Mg} 2+, \mathrm{Ca} 2+, \mathrm{Sr} 2+, \mathrm{Ba} 2+)$. Russ J Appl Chem 78:409-413.

Phutela, R.C., Pitzer, K.S. (1983) Thermodynamics of aqueous calcium chloride. J Solution Chem 12:201-207.

Pitzer, K.S. (1991) Activity Coefficients in Electrolyte Solutions, CRC Press, Boca Raton, FL.

Pontefract, A., Zhu, T.F., Walker, V.K., Hepburn, H., Lui, C., Zuber, M.T., Ruvkun, G., and Carr, C.E. (2017) Microbial diversity in a hypersaline sulfate lake: a terrestrial analog of ancient Mars. Front Microbiol 8:1819.

Postgate, J.R. and Hunter, J.R. (1961) On the survival of frozen bacteria. J Gen Microbiol 26:367-378.

Raymond-Bouchard, I., Chourey, K., Altshuler, I., Iyer, R., Hettich, R.L., and Whyte, L.G. (2017) Mechanisms of subzero growth in the cryophile Planococcus halocryophilus determined through proteomic analysis. Environ Microbiol 19:4460-4479.
Ronholm, J., Raymond-Bouchard, I., Creskey, M., Cyr, T., Cloutis, E.A., and Whyte, L.G. (2015) Characterizing the surface-exposed proteome of Planococcus halocryophilus during cryophilic growth. Extremophiles 19:619-629.

Rummel, J.D., Beaty, D.W., Jones, M.A., Bakermans, C., Barlow, N.G., Boston, P.J., Chevrier, V.F., Clark, B.C., Vera, J.-P.P., de, Gough, R.V., Hallsworth, J.E., Head, J.W., Hipkin, V.J., Kieft, T.L., McEwen, A.S., Mellon, M.T., Mikucki, J.A., Nicholson, W.L., Omelon, C.R., Peterson, R., Roden, E.E., Sherwood Lollar, B., Tanaka, K.L., Viola, D., and Wray, J.J. (2014) A new analysis of Mars "Special Regions": findings of the second MEPAG Special Regions Science Analysis Group (SR-SAG2). Astrobiology 14:887-968.

Smirnov, P., Wakita, H., and Yamaguchi, T. (1998) X-ray diffraction study on aqueous scandium(III) perchlorate and chloride solutions over the temperature range -45 to $95^{\circ} \mathrm{C}$. $J$ Phys Chem B 102:4802-4808.

Stillman, D.E. and Grimm, R.E. (2011) Dielectric signatures of adsorbed and salty liquid water at the Phoenix landing site, Mars. J Geophys Res 116:69.

Toner, J.D. and Catling, D.C. (2016) Water activities of Na$\mathrm{ClO} 4, \mathrm{Ca}(\mathrm{ClO} 4) 2$, and $\mathrm{Mg}(\mathrm{ClO} 4) 2$ brines from experimental heat capacities: water activity $>0.6$ below $200 \mathrm{~K}$. Geochim Cosmochim Acta 181:164-174.

Toner, J.D., Catling, D.C., and Light, B. (2015) Modeling salt precipitation from brines on Mars - evaporation versus freezing origin for soil salts. Icarus 250:451-461.

Wang, Y.-L., Wang, Y., and Yi, H.-B. (2016) High-order $\mathrm{Ca}$ (II)-chloro complexes in mixed caCl2-LiCl aqueous solution: insights from density functional theory and molecular dynamics simulations. J Phys Chem A 120:5635-5648.

Yamaguchi, T., Yamagami, M., Wakita, H., and Soper, A.K. (1995) Structure and dynamics of supercooled and glassy aqueous ionic solutions. In Studies in Physical and Theoretical Chemistry Structure, Fluctuation, and Relaxtion in Solutions, edited by H. Nomura, F. Kawaizumi, and J. Yarwood, Nagoya, Japan: Elsevier, pp 91-98.

Zavitsas, A.A. (2005) Aqueous solutions of calcium ions: hydration numbers and the effect of temperature. J Phys Chem B 109:20636-20640.

Address correspondence to: Jacob Heinz

Center of Astronomy and Astrophysics Technical University of Berlin Hardenbergstr. 36 Berlin 10623 Germany

E-mail: j.heinz@tu-berlin.de

Submitted 8 December 2017 Accepted 8 March 2018

\begin{tabular}{|c|} 
Abbreviations Used \\
CFUs $=$ colony forming units \\
$\mathrm{PBS}=$ phosphate-buffered saline \\
$\mathrm{RSL}=$ recurrent slope lineae \\
$\mathrm{ST}=$ sample type
\end{tabular}

